\title{
Pedagogical Training System of Future Social Workers in Ukraine: Experimental Study
}

\author{
Hanna A. Ridkodubska \\ Khmelnytskyi National University, Ukraine \\ https://orcid.org/0000-0003-0561-6835
}

Oksana Ya. Romanyshyna and Oksana Y. Karabin

Ternopil Volodymyr Hnatiuk National Pedagogical University, Ukraine https://orcid.org/0000-0002-2887-5023

https://orcid.org/0000-0001-8759-948X

Nataliia V. Kazakova

Khmelnytskyi Humanitarian Pedagogical Academy, Ukraine https://orcid.org/0000-0003-1499-3448

Halyna S. Tarasenko

Communal Higher Educational Institution "Vinnytsia Academy of Continuing

Education", Ukraine

https:// orcid.org/0000-0001-9394-2600

\begin{abstract}
This research is intended to reveal the study and experimental testing of the efficiency of the pedagogical system of training future social workers for professional mobility. The article substantiates theoretical and methodical framework for the training future social workers for professional mobility (PM). The pedagogical experiment was conducted in 2015-2019. The pedagogical training system of future social workers for PM was developed based on modern innovative pedagogical technologies. The result of this research is a well-ordered system of interrelated elements of the educational process that has a particular organization and structure. The structural-logical model combines independent subsystems represented by conceptual, technological, and performance evaluation structural blocks. As a result, the pedagogical conditions of training future social workers for PM was substantiated. It involved the creation of a positive motivational attitude of the future social workers towards PM, the introduction and application of innovative technologies of training future social workers for PM and the interdisciplinary coordination in the study of professional subjects.
\end{abstract}

Keywords: future social workers; professional mobility; pedagogical system; structural-functional model; social workers' readiness 


\section{Introduction}

Globalisation and integration processes are the essential features of modern society. They lead to the deepening of international relations, modernisation of processes in various spheres of human activity. Nowadays the labour market imposes requirements on the future specialists who are focused on success and continuous self-improvement. They should also be able to adapt quickly to new market demands, make independent and responsible decisions and work in the multicultural environment and multinational corporations.

Thus, the Ukrainian system of professional education is aimed at updating the training opportunities for professional mobility (PM) of students as one of the main tools of efficiency of the Bologna process implementation. The importance of ensuring the continuity of the educational process is argued in the laws of Ukraine (Legislation of Ukraine, 2014; 2017; 2019). The issues of the development of young people's and adults' motivation for lifelong learning play a significant role in these documents. This problem is focused on the Concepts of Continuing Teacher Development (Euroosvita, 2012) and in research papers of Ukrainian and foreign scholars (Agasisti, 2017; Baldwin \& Gould, 2016; Bogdanova, 2013; Cubberley, 2018; Sushentseva, 2017). They interpret knowledge about training as a new concept of professional activity in terms of technological and technocratic impacts on the quality of professional assistance by future specialists in the social sphere.

In Ukrain the process of developing a new educational system is focused on personal development and integration into the international educational space. In all spheres, especially in the social one, there are qualities of a specialist that become increasingly important. They include: adequate perception and mobile response to new professional tasks, social responsibility, dynamism, constructiveness, a developed sense of rapid adaptation in professional activity, independence and efficiency in decision-making, the readiness to adapt quickly to new working conditions and other qualities which determine a person's readiness for social and professional.

Professional mobility has been studied in sociology, particularly in the classical works of sociologists, such as Zaslavskaya and Ryvkina (1991), Lipset (2012), Sorokin (1992), Shubkin (2010) and others. The problem of training for PM was covered in the studies of Ukrainian and foreign scholars. The future specialists' training for professional activity (Bila, 2013) and personal mobility is studied (Bogdanova, 2013). The other studies focus on professional mobility of future specialists in economics (Ivanchenko, 2005) and social work (Kapska, 2005), social education (Polishchuk, 2012), professional mobility principles (Prima, 2010) and social mobility in developed countries (Romanovska, 2013; Sushentseva, 2017). The conditions determining professional mobility are identified by (Blau, 1964; 1977; 1995; Boddy, Cameron \& Petrie, 2006). Students' mobility is a precondition of academic achievements (Demie, 2002). However, mobility change throughout life (Dominelli, 2007; 2010; Ultee \& Luijkx, 1990). Therefore, the modern social work theory change (Payne, 2015). 
Therefore, the literature review helped identify the gap in the existing research and studies. The recent studies do not cover the experimental test of future social workers for professional mobility in Ukraine, as well as the modern pedagogical technologies and tools to be integrated in the teaching and learning processes in universities. The aims and objectives of this article is to study and experimentally test the efficiency of the pedagogical system of training future social workers for professional mobility.

\section{Research objectives:}

1. Analyse the efficiency of training future social workers for professional mobility.

2. Select and adapt the methods of diagnostics and criteria for measuring the future social workers' readiness for professional mobility accepted in psychological and pedagogical literature.

3. Outline promising directions of the work aimed at training future social workers for professional mobility.

The main hypotheses connected with testing the efficiency of pedagogical system based on future social workers sample are the following. H1: the developed pedagogical system of training future social workers for professional mobility is more efficient than traditional training pedagogical system. H2: The integration of new educational technologies in teaching and learning processes in universities, as well as in the training future social workers for professional mobility contributed to the increase in professional mobility of students.

\section{Research Methods}

This research is based on statistical analysis of the results obtained. The first research stage is bibliometric analysis of scientific papers prepared in the period of 1964-2020 in order to identify changes occurred in the theory and conceptual framework. Theoretical background and approach to conduct this research was chosen on this basis. The bibliometric analysis provides for determining tools for interpreting the results of the pedagogical experiment based on statistical analysis. The bibliometric analysis covers the period of the first half of 2015 academic year.

The next stage is the pedagogical experiment conducted during 2015-2019. The quasi-experimental study provided conducting the research by collecting data through the questionnaire. Quasi-experiment was used in the study of control (CG) and experimental (EG) groups, where the variables were added. The pedagogical experiment is used to measure the cause and effect relationship. The first stage of pedagogical experiment conducted during the second half of 2015 academic year is determinative. At this stage, representative sample was formed and empirical data were collected, traditional methods of training future social workers for PM are analyzed. The statistical analysis was based on mean values, percentage statistic indicators. The second stage of pedagogical experiment conducted during 2016 - the first half of 2019 academic year is formative. The experimental groups were formed at this stage. 
The third stage is statistical analysis carried out in 2019. At this stage, the results of the experimental study conducted based on identified determinative and formative research stages were analysed. The accuracy and reliability of the obtained results was proved based on mathematical statistics tools: mean and average percentage. The results validity was confirmed by the criterion for the implication of differences between mean values of the Student's t-test for independent samples. The determinative and formative stages of the experiment were conducted based on six institutions of higher education, where future social workers obtain their degrees. The determinative stage of the pedagogical experiment involved 97 students of the $4^{\text {th }}$ academic year in 2014-2015 studying for Speciality 6.130102 "Social work", and 18 lecturers, who conducted surveys, questionnaires, testing, control works and so on. The questionnaires and data were collected in classes.

The research was conducted with diagnostic tools used by the lecturers and at the formative stage of the research for students of control (CG) and experimental (EG) groups. The use of diagnostic tools enables determining the state of the future social workers' readiness for PM at four levels, which in the digital equivalent were indicated as follows: high - 5 scores; optimal - 4 scores; sufficient -3 scores; basic - 2 scores.

The pedagogical experiment was conducted based on tools and tests for diagnostics the professional orientation of future social workers. The next tools and tests were used:

1. Diagnosis of the research efficiency was carried out using the following methods: modified Rogov's method for establishing the professional orientation of a future social worker.

2. Adapted Yanchuk's method for determining the ability of students to match the real and ideal images of "self-identity" (Bodalev, 2010).

3. A modified version of Ivanov's and Kolobov's Mast-test for determining the vital values of future social workers (Fetiskin, Kozlov \& Manuilov, 2002).

4. Ehlers' "Motivation for Success" (Fetiskin et al., 2002) for determining motivational purposefulness of future social workers.

5. Vershlovskys's method, which enables revealing the changes of students' perceptions on the phenomenology of PM by revealing a subjective understanding of the meaning of the phrase "mobility of the future social worker", to clarify the formation of this quality in each student (Vershlovskys, 2002).

6. "Integrated Assessment of a Social Worker's Efficiency in Vocational Activity" (the method adapted by Fetiskin et al. (2002)).

7. The adapted method "Something New in Your Life", which reveals the level of the student's readiness for the adoption of new techniques, "Readiness for Professional Self-Development" method (Kodzhaspirova, 2005).

8. Berezhnova's adapted methodology-test of "Reflection on SelfDevelopment", questionnaire "Diagnosis of realization of the need for SelfDevelopment (Fetiskin et al., 2002).

9. Test "Are You Independent?" (Moskvina's (1996) method) for students to introduce their readiness for professional mobility. 
The next stage is statistical analysis of tests results. The statistical indicators were used to report the data of pedagogical experiment: mean, standard deviation. To confirm the validity of the experimental research, an empirical F-criterion was calculated, the numerical value of which was compared with the theoretical Fcriterion $\left(\mathrm{F}_{\text {crit }}\right)$. The reliability of the survey results was used by Cronbach's alpha. Cronbach's alpha is a measure of internal consistency, that is, how closely related a set of items are as a group. It is considered to be a measure of scale reliability. A "high" value for alpha does not imply that the measure is unidimensional (UCLA, n./d.). Its values range between zero (0) and one (1.00). A practical way to interpret the magnitude of a reliability coefficient can be the following scale (ResearchGate, 2016): 0.81 to 1.00 Very High; 0.61 to 0.80 High; 0.41 to 0.60 Medium; 0.21 to 0.40 Low; 0.01 to 0.20 Very Low. A reliability coefficient is considered acceptable at least at the upper limit (0.80) of the category "High".

The research was being conducted from 2015 to 2019 in four stages of scientificpedagogical search based on Kamianets-Podilskyi National Ivan Ohiienko University, Volodymyr Vynnychenko Central Ukrainian State Pedagogical University, Yurii Fedkovych Chernivtsi National University, the Municipal Establishment "Kharkiv Humanitarian-Pedagogical Academy" of the Kharkiv Regional Council, Khmelnytskyi National University, Ternopil National Economic University. At different stages of the study, 233 students were involved in the experiment: 97 future social workers (students of the $4^{\text {th }}$ academic year, Speciality 6.130102 "Social work") at the determinative stage, 68 students of control groups and 68 students of experimental groups participated in the formative stage, as well as 18 lecturers of higher educational institutions (HEIs).

\section{Research Results}

We interpret the professional mobility of future social workers as the ability to solve a wide range of problems in the social sector, the ability to acquire quickly new special skills, a willingness to cope with new professional functions which determine the specificities of providing professional assistance for different types of clients, to assimilate technologies, knowledge and skills successfully. We analysed the works of foreign scholars, in particular Dominelli (2010), who considers professional knowledge as the main feature of this process, Demie (2002) justifies preparation for professional activity as a prerequisite for training future specialists. Ukrainian scholars, in particular Sushentseva (2017) describes the features of preparation for PM, Prima (2010) determines features of PM development and concluded on the specifics of training of future workers for PM.

We distinguish the following features: acquiring professional knowledge, skills, gaining professional experience in performing tasks of a professionally oriented practice, developing new methods to assist the clients, studying the efficiency of customers' interaction; rapid independent decision-making; ability to behave differentially with people, understand people with respect to their needs and interests; determining the objectivity, active life position of future social workers. In order to optimize the process of training future social workers for PM, we consider aspects of implementing the international educational experience in training for professional mobility in Western Europe and America (RAND 
Corporation, n./d.). Ideas of openness (the ability to self-development) (Altbach, Berdahl \& Gumport, 2001), mobility (activation of all spheres of social life, flexible adaptation to the requirements of the labour market (Barr \& McClellan, 2018)), continuity (lifelong learning), advanced development (orientation at the future) are based on the professional training of social workers in the international educational environment). These ideas are constantly developing and they reflect a new perspective on achieving professional goals of training competitive specialists (Görlitz et al., 2015).

Future social workers' willingness for PM is determined as a unifying dynamic new formation in the personality's structure of future social workers, which actualizes the openness to change, the degree of understanding the need for mobility, manifests in the flexibility of thinking and adequate assessment of their professional tasks, balancing their capacities with the motives for professional self-development. The results of the research proved that training future social workers for PM becomes effective. The process effectiveness is regulated in accordance with scientifically grounded and developed pedagogical principles of the following approaches: system, individual-oriented (Payne, 2015), action (Ivanchenko, 2005), praxeological (Boddy et al., 2006), competent (Vyhrusch \& Romanyshyna, 2016), dialectical (Polishchuk, 2012), epistemological (Halatyr, 2010), synergetic (Altbach et al., 2011) approaches in the process of training future social workers for PM.

Based on the analysis of scientific sources and practical experience of training future social workers, the pedagogical conditions of training for PM were substantiated. The first pedagogical condition is the creation of a positive motivational attitude for the future social workers' $P M$. The second pedagogical condition is the introduction and application of innovative technologies of training future social workers for PM. We determine the interdisciplinary coordination in the study of professional disciplines as the third pedagogical condition. Interdisciplinary coordination is a system of forming an integrated viewpoint at mobility (Baldwin \& Gould, 2016).

Interdisciplinary coordination is intended to cover all sides of this phenomenon. That is why, if properly constructed, it will help to carry out qualitative training of future social workers for PM by means of methodically justified integrated use of different subjects, methods, forms and appropriate didactic materials. Therefore, we consider interdisciplinary coordination in the study of professional subjects as a real basis for training future social workers' PM, with the introduction of the following subjects: "Introduction to Major", "Social Work with Families, Children and Youth", "Practice of Social Activity", "Rehabilitation Work", "Social Work with Different Client Groups".

We consider the ability to adapt quickly to new conditions of professional activity, to solve difficult specialized issues and practical problems as readiness for PM. It implies the application of certain theories and are characterized by the complexity of conditions as the main indicator of future social workers' readiness for PM. 


\subsection{Determination of the process and result of training future social workers}

The developed model of the pedagogical system of training future social workers for PM has been viewed through its introduction into the teaching and learning process. The orientation of the structural and functional model is outlined in the determined components, divided into conceptual, technological, performance evaluation structural blocks. As a result, this provides the possibility of reproduction of the purposeful process of the integration system of PM training. The criteria of the integration system of PM training were defined: personal qualities of readiness for PM, the students' search and analytical qualities, students' professional capacities and skills.

The conceptual block accumulates the realization of the objective of motivation to be mobile and successful; forming a person's professional orientation, advanced personal and professional development; stimulating students to professional selfimprovement, self-development. The technological block of the structuralfunctional model of the pedagogical system of training future social workers for PM describes the substantive provision of the training process in the context of studying different subjects. The following subjects were introduced: "Introduction to Major" (1 1 st semester, $1^{\text {st }}$ academic year), "Social Work with Families, Children and Youth" (1 ${ }^{\text {st }}$ semester, $2^{\text {nd }}$ academic year $)$, "Practice of Social Activity" (1 ${ }^{\text {st }}$ semester, $3^{\text {rd }}$ academic year), "Rehabilitation Work" (1 ${ }^{\text {st }}$ semester, $4^{\text {th }}$ academic year), "Social Work with Different Client Groups" $\left(2^{\text {nd }}\right.$ semester, $4^{\text {th }}$ academic year). The performance evaluation block gives an idea of the efficiency of the process of training future social workers for PM at the level of relevant personal and professional qualities (personality, nature of activity, dynamics of self-development) (Figure 1). The pedagogical experiment aims at testing the hypothesis probability and its verification. Conducting a pedagogical experiment and research helped to achieve the outlined objectives in four stages.

The first stage (preparatory theoretical) was conducted during the first half of the 2015 academic year. At this stage, the bibliometric analysis of the scientific literature on foreign and Ukrainian experience was conduct based on the discussion of future social workers' professional training. The conceptual research approaches were clarified. The bibliometric analysis includes identification of peculiarities of training future social workers for PM. The results were compared based on pedagogical innovative and traditional technologies in educational process. The nature, structure, criteria and indicators were specified, and four levels (high, optimal, sufficient and basic) of the future social workers' readiness for PM were identified. The second stage (determinative) was conducted during the second half of 2015 academic year. At this stage, proper empirical information about the efficiency of traditional training future social workers for PM was collected and analysed. The relevance and reasonability of updating the students' training for PM were confirmed. A representative sample of groups of students, who subsequently participated in the experimental pedagogical research in control and experimental groups was created.

The third stage (formative) was conducted from 2016 until the first half of the 2019 academic year. At this experimental stage, a pedagogical system of training future social workers for PM was implemented in experimental groups. The theoretical 
background is the developed methodological support based on bibliometric analysis, pedagogical conditions that ensure its efficiency. The innovative pedagogical technologies (person-oriented, project, interactive) used include: training methods, case methods, presentations, game methods, practical assignments. Trainings, multimedia technologies were applied, independent work and all kinds of activities was organized. The fourth stage is statistical analysis conducted in 2019. At this stage, the results of experimental research conducted during the determinative and formative stages in Research Methods section were analyzed. The accuracy and reliability of the obtained results was proved by means of methods of mathematical statistics. The general conclusions of the study were drawn. Methodological recommendations for improving the efficiency of implementing the pedagogical system of training the future social workers for PM were developed.

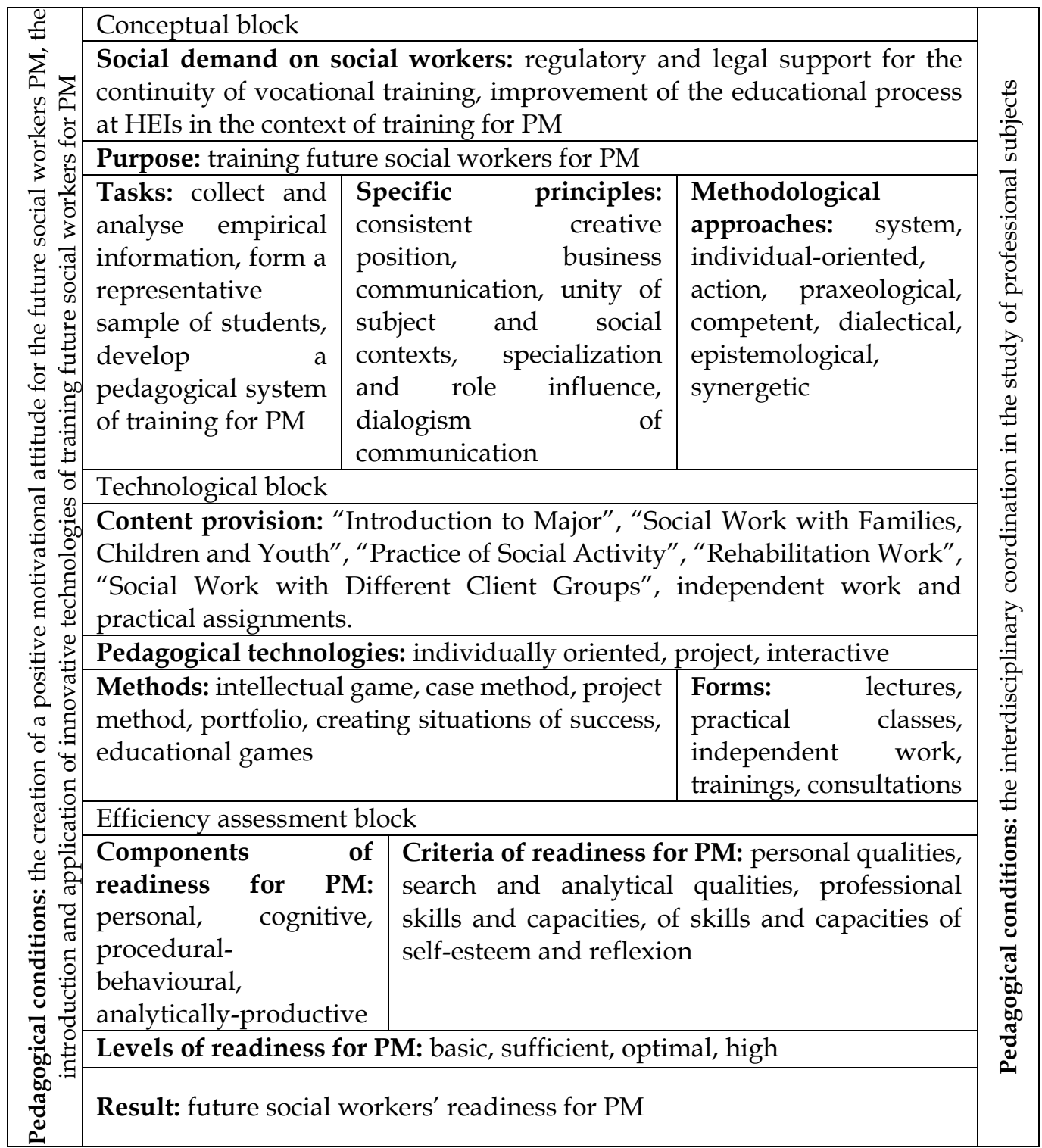

Source: author's development based on literature review

Figure 1: The structural-functional model of the pedagogical system of training future social workers for PM 
The determinative and formative stages of the experiment were conducted on the basis of six institutions of higher education, where future social workers obtain their degrees. Determinative stage of the pedagogical experiment involved 97 students of the $4^{\text {th }}$ academic year 2014-2015, Specialty: "Social Work" and 18 lecturers who conducted surveys, questionnaires, testing, control works and so on. The main purpose of conducting the determinative stage of the experiment was to diagnose the level of future social workers' readiness for PM, who have completed their training at the HEIs. The research was conducted with diagnostic tools used by the lecturers and at the formative stage of the research for students of control (CG) and experimental (EG) groups. This approach provided for the reliability of measuring the levels of personal, cognitive, procedural-behavioural, analytically-productive components of the future social workers' readiness for PM according to the determined criteria. The use of diagnostic tools enables determining the level of the future social workers' readiness for PM at four levels, which were indicated as follows in the digital equivalent: high -5 scores; optimal - 4 scores; sufficient - 3 scores; basic -2 scores.

The reliability statistics were calculated to assess reliability and validity of the results (Table 1). Cronbach's alpha is 0.706 for control group survey and 0.702 for experimental group survey. Therefore, the results are highly reliable.

Table 1: The reliability and validity statistics

\begin{tabular}{|l|c|c|c|}
\hline Reliability statistics & Cronbach's alpha & No of items & $\begin{array}{c}\text { No of } \\
\text { respondents }\end{array}$ \\
\hline $\begin{array}{l}\text { Future social workers at the } \\
\text { determinative stage }\end{array}$ & 0.712 & 45 & 97 \\
\hline Control group & 0.706 & 45 & 68 \\
\hline Experimental group & 0.702 & 45 & 68 \\
\hline
\end{tabular}

Based on processing and analysis of the obtained indicators and levels of each component of the future social workers' readiness for PM, the results of the determinative stage of the experiment were obtained as provided in Table 2.

Table 2: The levels of the future social workers' readiness for PM ( $4^{\text {th }}$ academic year) at the determinative stage of the experiment

\begin{tabular}{|c|c|c|c|c|c|c|c|c|c|}
\hline \multirow{3}{*}{ Components } & \multicolumn{8}{|c|}{$\begin{array}{l}\text { The levels of the future social workers' readiness } \\
\text { for PM }\end{array}$} & \multirow{3}{*}{$\begin{array}{l}\text { Average } \\
\text { score } \\
\text { (AS) }\end{array}$} \\
\hline & \multicolumn{2}{|c|}{$\begin{array}{c}\text { High } \\
\text { (5 scores) }\end{array}$} & \multicolumn{2}{|c|}{$\begin{array}{c}\text { Optimal } \\
\text { (4 scores) }\end{array}$} & \multicolumn{2}{|c|}{$\begin{array}{l}\text { Sufficient } \\
\text { (3 scores) }\end{array}$} & \multicolumn{2}{|c|}{$\begin{array}{c}\text { Basic } \\
\text { (2 scores) }\end{array}$} & \\
\hline & CG & $\%$ & CG & $\%$ & CG & $\%$ & $\mathrm{CG}$ & $\%$ & \\
\hline Personal & 25 & 25.8 & 53 & 54.6 & 19 & 19.6 & 0 & 0 & 4.1 \\
\hline Cognitive & 13 & 13.4 & 47 & 48.5 & 37 & 38.1 & & 0 & 3.8 \\
\hline Proced & 14 & 14.4 & 45 & 46.4 & 38 & 39.2 & 0 & 0 & \\
\hline Analytically-productive & 22 & 22.7 & 50 & 51.5 & 25 & 25.8 & 0 & 0 & 4.0 \\
\hline Readiness for PM & 18 & $\overline{18.6}$ & 48 & 49.5 & 31 & 31.9 & 0 & 0 & 3.9 \\
\hline
\end{tabular}

Designations: PM - professional mobility; CG - number of students; AS - average score

The analysis of the generalized indicators (Table 2) revealed the following levels of readiness of 97 future social workers of the $4^{\text {th }}$ academic year for PM: high - in 
18 students (18.6\%); optimal - in 48 students (49.5\%); sufficient - in 31 students (31.9\%); the basic level was not found; the average score was 3.9.

The obtained results of the determinative stage of the experiment determined the relevance and reasonability of developing additional pedagogical factors: the need to introduce the author's pedagogical system and its technological support to improve the efficiency of training future social workers. The positive impact and efficiency of the developed pedagogical system was proven through the

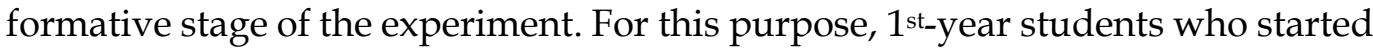
their studies in 2015-2016 academic year were divided into control (CG) and experimental (EG) groups. CG students were studying for four years according to the traditional model, and EG students were studying with the use of the author's pedagogical system of training for PM. The final control was conducted with the students of CG and EG in the period of completion their studies in the $4^{\text {th }}$ academic year of 2018-2019.

At the stage of generalization and analysis, a thorough analysis of the results of the stages of input and output controls of the experiment was conducted, the numerical values of the levels of each component of future social workers' readiness for PM were compared by the indicators of input control (IC) and output control (OC). The generalized results of training future social workers for PM, which reflect the complex development of all components of readiness, at the stages of input and output controls are presented in Table 3.

Table 3: The levels of the future social workers' readiness for PM at the stages of input and output controls

\begin{tabular}{|c|c|c|c|c|c|c|c|c|c|}
\hline \multirow{3}{*}{$\begin{array}{l}\text { Groups - control phase - } \\
\text { number of students }\end{array}$} & \multicolumn{8}{|c|}{$\begin{array}{l}\text { The levels of the future social workers' } \\
\text { readiness for PM }\end{array}$} & \multirow{3}{*}{ AS } \\
\hline & \multicolumn{2}{|c|}{$\begin{array}{c}\text { High } \\
\text { (5 scores) }\end{array}$} & \multicolumn{2}{|c|}{$\begin{array}{l}\text { Optimal } \\
\text { (4 scores) }\end{array}$} & \multicolumn{2}{|c|}{$\begin{array}{l}\text { Sufficient } \\
\text { (3 scores) }\end{array}$} & \multicolumn{2}{|c|}{$\begin{array}{c}\text { Basic } \\
(2 \text { scores })\end{array}$} & \\
\hline & NS & $\%$ & NS & $\%$ & NS & $\%$ & NS & $\%$ & \\
\hline CG - IC - 68 students & 11 & 16.2 & 26 & 38.2 & 28 & 41.2 & 3 & 4.4 & 3.7 \\
\hline CG - OC - 62 students & 14 & 22.6 & 29 & 46.8 & 19 & 30.6 & 0 & 0 & 3.9 \\
\hline EG - IC - 68 students & 10 & 14.7 & 27 & 39.7 & 27 & 39.7 & 4 & 5.9 & 3.6 \\
\hline EG - OC - 64 students & 20 & 31.3 & 34 & 53.1 & 10 & 15.6 & 0 & 0 & 4.2 \\
\hline
\end{tabular}

The data analysis of the Table 3 confirms the efficiency of implementing the author's experimental pedagogical system in the educational process of HEIs, because in terms of indicators of all levels and the average score, the EG students showed more significant changes than the CG students as regards training future social workers for PM. Comparison of the results of changes in training future social workers for PM in the context of traditional training showed that no significant changes occurred in CG. Mathematical statistics methods used in professional pedagogy were applied to prove the results of the experimental study. The reliability of the results in the formation of CG and EG was established by calculating the criteria by the Student's $t$ test or t-distribution (shift index and dynamics). 
The data analysis of Table 3 enables summarizing the findings of the determinative stage of the experiment (DSE) obtained in 2014-2015 academic year with $4^{\text {th }}$ year students, and the results of the output control in CG (OC-CG), obtained in 2018-2019 academic year in CG, which were almost identical at all levels and the same in terms of the average score (3.9), in contrast to the output control in the EG, where the average score was 4.2 points. The differences in the criteria and levels, that is, between the achievements of the participants in the experimental and control groups are statistically relevant and significant. The analysis of the indicators of Table 3 and the calculation of the Student's t-test indicates the achievement of reliability in the distribution of students with the specified levels (Table 4).

Table 4: The state of future social workers' readiness of for professional mobility by levels

\begin{tabular}{|c|c|c|c|c|c|c|c|c|c|}
\hline \multirow{3}{*}{$\begin{array}{l}\text { Groups - control phase - } \\
\text { number of students }\end{array}$} & \multicolumn{8}{|c|}{$\begin{array}{l}\text { The state of future social workers' readiness } \\
\text { of for professional mobility by levels }\end{array}$} & \multirow{3}{*}{ AS } \\
\hline & \multicolumn{2}{|c|}{$\begin{array}{l}\text { High }(5 \\
\text { scores })\end{array}$} & \multicolumn{2}{|c|}{$\begin{array}{l}\text { Optimal } \\
\text { (4 scores) }\end{array}$} & \multicolumn{2}{|c|}{$\begin{array}{l}\text { Sufficient } \\
\text { (3 scores) }\end{array}$} & \multicolumn{2}{|c|}{$\begin{array}{l}\text { Basic }(2 \\
\text { scores) }\end{array}$} & \\
\hline & NS & $\%$ & NS & $\%$ & NS & $\%$ & NS & $\%$ & \\
\hline CE - IC - 97 students & 18 & 18.6 & 48 & 49.5 & 31 & 31.9 & 0 & 0 & 3.9 \\
\hline CG - OC - 62 students & 14 & 22.6 & 29 & 46.8 & 19 & 30.6 & 0 & 0 & 3.9 \\
\hline EG - OC - 64 students & 20 & 31.3 & 34 & 53.1 & 10 & 15.6 & 0 & 0 & 4.2 \\
\hline
\end{tabular}

To confirm the validity of the results of the experiment, an empirical F-criterion $\left(\mathrm{F}_{e m p}-\mathrm{CG}\right.$ and $\left.\mathrm{F}_{e m p}-\mathrm{EG}\right)$ was calculated, the value of which was compared with the Table value (Table 5) of the theoretical F-criterion $\left(\mathrm{F}_{\text {crit }}\right)$. The $\mathrm{F}_{\text {crit }}$ index for our research was determined by the number of degrees of freedom (Table 5), which was determined by subtracting one unit from the number of students in the group. Thus, in the CG, where the number of students was 68 and 62, and in the EG, which had 68 and 64 students, the F-criterion should be in range of 1.7-1.3 (for the number of degrees of freedom 60-120).

Table 5: Results of F-criterion calculations for generalized indicators

\begin{tabular}{|c|c|c|c|c|c|c|c|c|c|c|c|c|}
\hline \multirow{3}{*}{$\begin{array}{l}\text { Groups } \\
\text { - control } \\
\text { stage }\end{array}$} & \multirow{3}{*}{ AS } & \multicolumn{10}{|c|}{ Indicators for determining the F-criterion } & \multirow{3}{*}{$\mathrm{F}_{\text {emp }}$} \\
\hline & & \multicolumn{4}{|c|}{$f$} & \multicolumn{4}{|c|}{$\left(x_{i}-\bar{x}\right)$} & \multirow{2}{*}{$\sum f\left(x_{i}-\bar{x}\right)^{2}$} & \multirow{2}{*}{$\sigma^{2}$} & \\
\hline & & 5 & 4 & 3 & 2 & 5 & 4 & 3 & 2 & & & \\
\hline CG-IC & 3.66 & 11 & 26 & 28 & 3 & 1.34 & 0.34 & -0.66 & -1.66 & 43.22 & 0.64 & \multirow{2}{*}{1.2} \\
\hline CG-OC & 3.91 & 14 & 29 & 19 & 0 & 1.08 & 0.08 & -0.92 & -1.92 & 32.6 & 0.53 & \\
\hline EG -IC & 3.63 & 10 & 27 & 27 & 4 & 1.37 & 0.37 & -0.63 & -1.63 & 43.81 & 0.64 & \multirow{2}{*}{1.5} \\
\hline EG-OC & 4.16 & 20 & 34 & 10 & 0 & 0.84 & -0.16 & -1.16 & -2.16 & 28.44 & 0.44 & \\
\hline
\end{tabular}

To determine the empirical F-criterion, general parameters (averages and variances) were compared for each component and future social workers' overall readiness for professional mobility. Analysis of indicators of Table 5 allows us to summarize that F-criterion for $\mathrm{CG}\left(\mathrm{F}_{\text {emp }}-\mathrm{CG}=1.2\right)$ goes beyond the standard tabular data (1.7-1.3). Therefore, a slight increase in the level of each component and the overall readiness of the future social workers who studied in the control 
groups for $\mathrm{PM}$, is related to the natural conditions of the traditional educational process at HEIs. The F-criterion for the experimental groups $\left(\mathrm{F}_{e m p}-\mathrm{EG}=1.5\right)$ is within the standard table (1.7-1.3). This means that the results of our research are reliable and confirm the validity of the experiment. Thus, the levels of future social workers' readiness for PM depend on the purposeful implementation of the developed pedagogical author's system. The results of the experimental study have been confirmed by reliable indicators, verified by the methods of mathematical statistics.

\section{Discussion}

In the conditions of irreversible transformations, which are taking place in Ukrainian society, the problem of reforming all spheres of life of the society becomes more acute. The development of professional mobility of future specialists, which is a prerequisite for the effective restructuring of socio-economic problems, harmonization of cultural and intellectual levels of different population groups, undoubtedly leads to the achievement of social justice, and therefore, the stability of the society. The consequence of the interaction of the conditioned processes is the activation of the redistribution of new and change of the already existing spheres of professional activity of future specialists, which, in turn, causes the redistribution of professional units in the labour market, motivated by the emergence of new requirements, adequate requirements of the time and the sphere of professional activity (Halatyr, 2010; Prima, 2010 and others). This reveals the relevance of the issue of future specialists' professional mobility, since professional mobility is one of the most significant characteristics of human interaction and professional activity. The bibliometric analysis showed that considerable experience was gained in the pedagogical theory and practice of Ukraine. It could become the basis for future social workers' professional training (Kapska, 2005; Nychkalo, 2015; Polishchuk, 2012 and others). The analysis of the quality problem of professional education was carried out (Sushentseva, 2017; Vyhrusch \& Romanyshyna, 2016 and others).

At the same time, there are no specific studies that would directly address the training of future social workers for professional mobility, which is determined by the development of multi-professional qualities of future specialists, which are the basis for the development of professional competence. Some areas of research problems of training future social workers for professional mobility have not been covered. The first problem is a lack of pedagogical system of scientific and methodological training of social workers for professional mobility. The second problem is the lack of scientific and pedagogical support of the process oriented towards training for professional mobility. The third problem is the insufficient use of innovative technologies that would provide qualitative dynamic changes in training future social workers for future mobility at the HEIs. The fourth problem is the existing need for system-integrative organization of training future social workers for professional mobility and the lack of a conceptual justification in the theory and methodology of professional education.

The reliability of the research results were due to the system of methods and techniques for studying the efficiency of training future social workers for 
professional mobility, the objectivity of the data obtained was confirmed by Student's t-test, the conclusions are based on the reasonability of providing the main components of the studied system. The conducted research confirmed the assumption that the use of pedagogical training system of social workers improves the quality of the development of readiness of future specialists in the social sphere for PM.

\section{Conclusion}

We interpret the future social workers' professional mobility as the ability of future social workers to fulfil a wide range of tasks in the social field. Training future social workers for professional mobility is a dynamic consistent pedagogical process that changes due to innovative technologies implemented by introducing forms and methods of training aimed at forming an individual who is ready for self-development, self-building and adaptation. The pedagogical conditions for training future social workers for PM were identified, and the method of their realization was scientifically substantiated. The pedagogical conditions are the following: the creation of a positive motivational attitude of the future social workers towards PM, the introduction and application of innovative technologies of training future social workers for PM, the interdisciplinary coordination in the study of professional subjects. Therefore, the trainer should be a leader and motivate future workers, create motivational environment. In order to realise this recommendation, universities should test the teachers at regular intervals based on special motivational questionnaire.

The experimental results illustrate positive changes in the future social workers' readiness for PM. The analysis of the results of the experiment confirmed the pedagogical reasonability of the substantiated conceptual approaches for the development and implementation of the author's pedagogical system of training future social workers for PM. The research was limited in terms of the respondent's sample, as the participants of the control and experimental groups were students of the faculties of pedagogy. The results were not tested on students from different specialities. Therefore, the results cannot be extended to other specialities. Promising area of development of the problem is the development of readiness of bachelors' and masters' of social studies in the context of modern realities connected with the globalization of intellectual potential, leading educational and fundamental achievements for the purpose of self-development and professional growth of future social workers.

\section{References}

Agasisti, T. (2017). Management of Higher Education Institutions and the Evaluation of their Efficiency and Performance. Tertiary Education and Management, 23(3), 187 190. https://doi.org/10.1080/13583883.2017.1336250

Altbach, P. G., Berdahl, R. O., \& Gumport, P. J. (2001). American Higher Education in the 21st Century. Baltimore, MD: The John Hopkins University Press.

Baldwin, M., \& Gould, N. (Eds.), (2016). Social work, critical reflection and the learning organization. Abingdon, UK: Routledge.

Bila, O. O. (2013). Preparation of future specialists in the social sphere for the design of professional activity: theory and practice: monograph. Odessa, Ukraine: Astroprint.

Blau, P. (1964). Exchange and power in social life. New York, US: Wiley. 
Blau, P. (1977). Inequality and heterogeneity. New York, US: Free press.

Blau, P. (1995). The dynamic of bureaucracy. Chicago, IL: The University of Chicago Press.

Bodalev, A. A. (2010). Psychology of communication. Encyclopedic Dictionary. Moscow, Russia: Kogito-Center.

Boddy, J., Cameron, C., \& Petrie, P. (2006). The professional care worker: The social pedagogue in Northern Europe. In: J. Boddy, C. Cameron, \& P. Moss (Eds.), Care Work: Present and Future (pp. 93-110). Abingdon, UK: Routledge.

Bogdanova, I. M. (2013). Personal mobilization of the future teacher as a subject of psychological and pedagogical research: textbook guide. Odessa, Ukraine: Bukaev Vadim Viktorovich.

Cubberley, E. (2018). The History of Education. London, UK: Forgotten Books.

Demie, F. (2002). Pupil mobility and education achievement in schools: an empirical analysis. Educational Research, 44(2), 197-215.

Dominelli, L. (2007). Contemporary Challenges to Social Work Education in the United Kingdom. Australian Social Work, 60(1), 29-45.

Dominelli, L. (2010). Social Work in a Globalizing World. Cambridge, UK: Polity Press.

Euroosvita. (2012). Concept of development of continuous pedagogical education from MONMs leaves without modification of the existing system. Retrieved from http:/ / www.euroosvita.net/index.php/?category=1\&id=2222

Fetiskin, N. P., Kozlov, V. V., \& Manuilov, G. M. (2002). Socio-psychological diagnosis of the development of personality and small groups. Moscow, Russia: Institute of Psychotherapy.

Görlitz, A., Ebert, T., Bauer, D., Grasl, M., Hofer, M., Lammerding-Köppel, M., \& Fabry, G. (2015). Core competencies for medical teachers (KLM) - A position paper of the GMA Committee on personal and organizational development in teaching. GMS Zeitschrift fur medizinische Ausbildung, 32(2), Doc. 23. https://doi.org/10.3205/zma000965

Halatyr, I. A. (2010). The content and organization of practical training highly qualified specialists in the field of social pedagogy and social work in some European countries. Proceedings of Khmelnytsky Social Technologies Institute of the Ukraine University, 2, 66-69.

Ivanchenko, E. A. (2005). Formation of professional mobility of future economists in the process of education in higher educational establishments (PhD dissertation). K. D. Ushynsky South Ukrainian State Pedagogical University, Odesa, Ukraine.

Kapska, A. Y. (2005). Social work: textbook. Kyiv, Ukraine: Center for Educational Literature.

Kodzhaspirova, G. M. (2005). Dictionary of pedagogy (interdisciplinary): for students, studios, graduate students, teachers and university professors. Moscow; Rostov on Don, Russia: ICT Mart.

Legislation of Ukraine. (2014). Law of Ukraine "On higher education". Retrieved from http://zakon3.rada.gov.ua/laws/show/1556-18

Legislation of Ukraine. (2017). Law of Ukraine "On education". Retrieved from https://zakon.rada.gov.ua/laws/show/2145-19

Legislation of Ukraine. (2019). Law of Ukraine "About social services". Retrieved from https://zakon.rada.gov.ua/laws/show/2671-19

Lipset, S. M. (2012). Some Social Prerequisites for Democracy: Economic Development and Political Legitimacy. In D. V. Efremenko, \& E. Yu. Meleshkina (Eds.), The concept of modernization in foreign socio-political theory 1950-1960 (pp. 35-86). Moscow, Russia: RAS. INION.

Moskvina, L. (1996). Encyclopedia of psychological tests. Saratov, Russia: Scientific Book. 
Nychkalo, N. G. (2015). Continuity of professional education: philosophical and pedagogical aspects. Proceedings of The International Scientific and Practical Conference: Quality of continuous education in the context of European integration processes: tendencies, problems, forecasts (pp. 5-14). Chernivtsi, Ukraine.

Payne, M. (2015). Modern social work theory. Oxford, UK: Oxford University Press.

Polishchuk, V. A. (2012). Social Education: An Encyclopedia for Social Workers. Kyiv; Simferopol, Ukraine: Universam.

Prima, R. M. (2010). Theoretical and methodological principles of forming the professional mobility of the future teacher of primary education (Doctoral thesis abstract). K. D. Ushynsky South Ukrainian State Pedagogical University, Odesa, Ukraine.

RAND Corporation. (n./d.). Educational Administration. Retrieved from https://www.rand.org/topics/educational-administration.html

ResearchGate. (2016). Question: How do I interpret my Alpha Cronbach value? Retrieved from https://www.researchgate.net/post/How_do_i_interpret_my_Alpha_cronbach _value

Romanovska, L. I. (2013). System of training of social workers abroad by example of developed countries. Collection of scientific works of the National Academy of the State Border Guard Service of Ukraine. Series: Pedagogical Sciences, 3. Retrieved from http://nbuv.gov.ua/UJRN/Vnadps_2013_3_21

Shubkin, V. N. (2010). Sociology and society: Scientific knowledge and ethics of science: monograph. Moscow, Russia: TsSPiM.

Sorokin, P. (1992). Man. Civilization. Society. Moscow, Russia: Politizdat.

Sushentseva, L. L. (2017). Adaptation of young people in the labor market as a modern pedagogical problem. Collection of abstracts of the XIII scientific-practical conference: Problems and prospects of development of economy and entrepreneurship and computer technologies in Ukraine (pp. 107-108). Lviv, Ukraine.

UCLA. (n./d.). What does Cronbach's Alpha mean? Retrieved from https://stats.idre.ucla.edu/spss/faq/what-does-cronbachs-alpha-mean/

Ultee, W. C., \& Luijkx, R. (1990). Educational heteronomy and father-to-son occupational mobility in 23 industrial nations. European Sociological Review, 6(2), 125-150.

Vershlovsky, S. G. (2002). Adult education: experience and problems. Moscow, Russia: Knowledge.

Vyhrusch, V., \& Romanyshyna, L. (2016). Autodidacticism as an attempt to rethink the nature of the educational process in private primary education: the end of the XIX - the beginning of the XX century. Development of Ukrainian and Polish Education and Pedagogical Thought (XIX-XXI centuries), 6, 52-65.

Zaslavskaya, T. I., \& Ryvkina, R. V. (1991). Sociology of economic life: Essays on the theory. Novosibirsk, Russia: NSU Publ. 